\title{
Is there a need for conservation of honeybees in Africa?*
}

\author{
Vincent DIETEMANN ${ }^{1,2}$, Christian Walter Werner PIRK ${ }^{2}$, Robin $_{\text {CREWE }}^{2}$ \\ ${ }^{1}$ Swiss Bee Research Centre, Agroscope Liebefeld-Posieux Research Station ALP, 3003 Bern, Switzerland \\ ${ }^{2}$ Social Insect Research Group, Department of Zoology and Entomology, University of Pretoria, 0002 Pretoria, \\ South Africa
}

Received 11 November 2008 - Revised 5 December 2008 - Accepted 17 December 2008

\begin{abstract}
Honeybees are native to Africa and Europe but have been spread worldwide as the basis for an apicultural industry. To date, large and diverse wild populations only remain in Africa. On this continent the beekeeping industry is relatively undeveloped and relies on trapping swarms from wild populations to constitute the managed stocks. Bee breeding is seldom practiced. The situation is therefore different from that of Europe or North America where wild or feral honeybees have almost disappeared and this distinction is important when assessing the conservation status of African honeybees. While African honeybees appear to be more resistant to major diseases, the history of honeybee populations worldwide suggests that their conservation is a necessity. After analyzing the threats to which honeybees are exposed in Africa, we argue that preventive conservation measures are required to maintain the present favorable situation and avoid the declines in populations experienced elsewhere.
\end{abstract}

conservation / honeybee / Apis / Africa / diseases / beekeeping

\section{INTRODUCTION}

The relationship between humans and honeybees in Africa takes several forms: honey hunting is practiced in many countries (Hepburn and Radloff, 1998, p. 172, p. 205; Crane, 1999); traditional beekeeping based on keeping colonies in woven baskets, clay, bark, grass or log hives is widespread in some countries whereas others adopted modern beekeeping techniques using hives with removable frames (Langstroth, top bar hives; Johannsmeier, 2001; Kidd and Schrimpf, 2000). The major difference in context compared to other regions of the world where honeybees are native or have been introduced is the important wild honeybee population (Moritz et al., 2005; Jaffe et al., unpubl. data) on which hunting and exploitation are based. In contrast with Europe, managed

Corresponding author: C.W.W. Pirk, cwwpirk@zoology.up.ac.za

* Manuscript editor: Mark Brown honeybees only constitute a small fraction of the population (Moritz et al., 2007; Jaffe et al., unpubl. data), an important distinction to be considered for the conservation of this pollinator. Another major difference between African and European populations (i.e. continents in which honeybees are endemic) is the fact that in Africa, beekeeping is mostly based on swarms trapped from the wild, whereas in Europe, breeding has affected population structure (De la Rúa et al., 2009). This is especially true since the selection performed through breeding is not diluted via uncontrolled mating with wild honeybees since wild populations have almost disappeared (Moritz et al., 2007; Jaffe et al., unpubl. data). We estimate the number of wild colonies in Africa to be 310 million colonies (based on a density of 12 colonies $\backslash \mathrm{km}^{2}$, Kajobe and Roubik, 2006 and correcting for desert areas), whereas there are only around 11.5 million colonies in Europe (EC, 2004; De la Rúa et al., 2009). In other words, beekeeping in Africa uses a small 
part of the wild population, whereas in Europe wild populations play a small role in determining population structure that mainly results from beekeeping activities (i.e. translocations and selections).

Given the large natural stocks and absence of immediate danger to African honeybees, one could conclude that there is no need for honeybee conservation in Africa, but we argue here honeybees deserve conservation in order to ensure that colony losses experienced in other parts of the world are not repeated in Africa. In addition, the genetic diversity represented by the different populations on the continent (Hepburn and Radloff, 1998) needs to be protected.

\section{STATUS OF BEEKEEPING IN AFRICA}

Traditional beekeeping still dominates modern beekeeping in many African countries such as Ethiopia, Ghana, Guinea-Bissau, Morocco, Mozambique, Nigeria, Senegal, Somalia, Sudan, Tunisia, Tanzania, Uganda, Zambia, Zimbabwe (Hussein, 2000). In other countries such as Kenya, Egypt, Tunisia (Hussein, 2000) and South Africa (Johannsmeier, 2001) modern beekeeping prevails. In South Africa, according to Johannsmeier (2001), there was a direct transition from honey hunting to modern beekeeping in the mid 1800 s because of the absence of suitable material to build bark hives and of regular honey flow to sustain harvesting. Managed honeybees amount to 14-18 million hives in the whole of Africa (Crane, 1990; Hussein, 2000; Johannsmeier, 2001), in comparison to more than 10 million wild colonies estimated for South Africa alone (Jaffe et al., unpubl. data) and to more than 310 million colonies on the continent. Beekeeping businesses in Africa are mainly small scale supplementary cash income schemes often promoted by rural developmental projects. Beekeepers in North, West and East Africa possess on average 15 hives (Hussein, 2000) and large scale enterprises ( $>250$ hives) are mostly found in Tanzania, Zambia and in South Africa where $20 \%$ of the beekeepers possess $75 \%$ of the hives in the Western Cape for example (Ntenga and Mugongo, 1991; Clauss, 1992). At a national level, 50 out of the 3000 South African beekeepers are estimated to produce $80 \%$ of the honey (Total transformation Agribusiness report, 2004). Given the small number of commercial beekeepers and the low economic importance of bee related products in Africa, the network of associations and institutes supporting the beekeeping industry is poorly developed and little data on managed honeybee population health is available. The information available for stingless bees sometimes used in traditional and modern beekeeping is even sparser (see the article by Eardley et al., in this issue). Such dearth of information suggests two possibilities: African honeybees are healthy and all is well, or they are threatened by various factors but this is not recognized for lack of surveys to establish their significance. The potential threats to which African honeybees are exposed, are discussed below in order to determine conservation actions that need to be put in place.

\section{WHAT ARE THE THREATS?}

African honeybees are exposed to several threats such as hunting, habitat loss or diseases. Most recognized honeybee diseases are present in Africa (Bradbear, 1988; Matheson, 1996; Hussein, 2000), either as imported or local pests.

\subsection{Varroa (imported)}

The presence of Varroa destructor was discovered in South Africa in Cape Town in 1997 (Allsopp, 1997) and was found close to the borders of Botswana, Mozambique, Swaziland and Zimbabwe in 2002, indicating that it has since reached neighboring countries as several reports suggest $(V$. destructor has arrived in Zimbabwe, Scholmke and Schmolke, 2003; Allsopp, 2006). Despite concerns about the effect that this parasite would have in South Africa, since it has resulted in important bee mortality outside of its native 
range (Allsopp, 2004), in South Africa Apis mellifera scutellata and A. m. capensis are tolerant and seem to coexist with the imported mite without dramatic effects (Allsopp, 2006; see also Ritter et al., 1990). V. destructor is also present in North Africa (Algeria, Morrocco, Lybia, Tunisia, Niger; Bradbear, 1988; Ongus, 2006) and has been reported in West Africa in 2007 (Sénégal, http://www. apiculturetropicalejosephchauvin-vautier.

$\mathrm{fr} /$ ). Wherever this mite has been studied in Africa, honeybees seem to tolerate them without apparent detrimental effects once the initial infestation stage is passed. Reasons for this tolerance are still debated (Mondragón et al., 2005; Ibrahim and Spivak 2007). An exception occurs in North Africa (Algeria, Tunesia, Morrocco) where dramatic losses were experienced for a couple of years after introduction of the mite. Chemical control methods allowed them to develop an equilibrium after a few years. The expression of clinical symptoms were again confirmed in Morocco in 2005 and Algeria in 2007 (WAHID interface OIE: http://www.oie.int/ wahis/public.php). It is not clear whether tolerance could not be established due to the use of early methods of control or whether A. $m$. intermissa is more susceptible to the mite than the other African subspecies. The report of clinical symptoms of $V$. destructor infestation in 2007 for Zimbabwe is curious (WAHID interface OIE) since tolerance by $A$. $m$. scutellata should have developed following the invasion in 2002 as it did in South Africa within 4-5 years after introduction (Allsopp, 2006).

\subsection{Viruses, bacteria, fungi (imported and local)}

Little and outdated data is available for Africa (Bradbear, 1988; Matheson, 1996; Hussein, 2000). American foulbrood is either absent or present at low levels in Africa despite the introduction of spores from other parts of world (Fries and Raina, 2003). In general, larvae of honeybees of African origin show a lower mortality than their European counterparts (Danka and Villa, 1994).
In general, the available data suggests that there is a higher frequency of disease in countries where beekeeping activities have been developed (Hussein, 2000). This could indicate a causal relationship between beekeeping activity and disease transfer (Morse and Flottum, 1997) but could also originate in a sampling bias, more data being available where surveys are available. Despite the occurrence of these diseases no problems have been reported, again indicating that African honeybees are either not threatened or that health surveys are deficient.

\subsection{Small hive beetle (local)}

Small hive beetles (Aethina tumida Murray) represent no threat in sub-Saharan Africa since it is endemic to this region (Lundie, 1940; El-Niweiri et al., 2008) and bees coevolved with it. They only represent minor pests since they infest weakened colonies (Lundie, 1940; Neumann and Elzen, 2004). Like Varroa mites, they developed into serious problems when they were exposed to new hosts (European honeybees) in the United States of America and Australia (Neumann and Elzen, 2004). In the northern part of the continent, their presence was reported in Egypt along the Nile river and in Sudan (Mostafa and Williams, 2000; Neumann and Elzen, 2004; El-Niweiri et al., 2008), but they do not seem to have established there according to recent large scale surveys that found them to be either absent or very scarce (Hassan and Neumann, 2008; El-Niweiri et al., 2008).

\subsection{Other honeybees (local)}

In the late 1970s and early 1980s, South African scientists and beekeepers were concerned about the possibility that the neighbouring subspecies A. $m$ scutellata or other honeybees might invade the restricted distribution area of $A$. m. capensis in the southern part of the country (Ruttner, 1977; Anderson, 1980). Due to its restricted range A. m. capensis was considered to be a unique population adapted to the particular biotope of the 
fynbos vegetation and to the particular climatic conditions of the region characterized by winter rainfalls (Ruttner, 1977; Tribe, 1983; Hepburn and Guillarmod, 1991). These concerns were not supported by later observations since the introgression zone between the two races remained constant in time despite natural and human induced migrations of colonies across this zone. This may be due to the fact that A. m. capensis behaves as a social parasite when entering colonies of other subspecies of honeybees (Neumann and Hepburn, 2002), which would stop the expansion of the neighbouring subspecies into the A. m. capensis area. Ironically, the ability to produce socially parasitic workers was at the origin, two decades later, of concerns that it is in fact $A . m$. capensis that is threatening to invade $A$. $m$. scutellata through this facultative socially parasitic trait. During their migration activities, beekeepers moved colonies of $A . m$. capensis into the distribution area of A. m. scutellata and subsequently sold these colonies to local beekeepers or moved A. m. scutellata colonies to the Cape region where $A$. $m$. capensis occurs before taking them back to their original area. This triggered a large scale spread of parasitic $A$. m. capensis workers into A. $m$. scutellata colonies with the consequent death of thousands of colonies (Crewe and Allsopp, 1993; Dietemann et al., 2006). However, initial concerns proved to be unfounded since the parasites do not significantly affect the wild populations (Härtel et al., 2006). It nevertheless resulted in important economic losses for the beekeepers who are the vectors of this parasite (Dietemann et al., 2006). Beekeepers mostly compensate for their losses by trapping new wild swarms to rebuild their stocks. The parasite's presence could thus affect wild populations indirectly through increased trapping. However, the significance of such an effect has not been investigated.

\subsection{Other honeybees (imported)}

Hepburn and Radloff (1998) reviewed the numerous attempts by beekeepers to introduce European honeybees to Africa. They argued that due to poor adaptation to local climate and poor defences against parasites and predators, honeybees of European origin failed to establish in Africa. This idea is supported by studies in South America demonstrating that although there is gene flow between honeybees of African and European origin (Sheppard et al., 1991), the African characteristics tend to replace European ones (Schneider et al., 2004). However, introduction of A. florea resulted in successful establishment of a population in Sudan. This success could be due to the tropical origin of $A$. florea which has been invading this country since 1983/1984 at a rate of $20 \mathrm{~km}$ per year (Mogga et al., 1989; El Shafie et al., 2002). However, there seems to be no competition with the local A. m. yemenitica (Mogga, 1994; El-Shafie et al., 2002; wrongly named A. m. sudanensis, see Hepburn and Radloff, 1998 for more details). Although they share pollen sources to a great extent, their foraging times differ and this suggests that they may not be in direct competition for local resources. Despite the apparent lack of effect noted by beekeepers, the absence of reference data before the invasion took place makes it impossible to determine whether there is competition between the species. Although nothing can be done to stop the invasion, its development should be monitored since a great part of Africa appears suitable for establishment of A. florea (Hepburn and Radloff, 1998), especially once it reaches the tropical regions.

\subsection{Habitat loss}

Habitat loss in Africa could be the most significant factor affecting honeybee populations. Although the human population doubled in size between 1980 and 2000 implying the development of cities and settlements, decrease in forested area through land exploitation has a greater impact. Indeed, honeybees mostly nest in hollow trees and deforestation could affect them drastically. Between 2000 and 2005, 4 million hectares were destroyed per year (i.e. $0.62 \%$ loss of surface area; Kelatwang and Garzuglia, 2006; Iremonger et al., 1997). Another 400 million hectares of less densely wooded areas could be suitable for nesting. 
Replacement of natural forest by plantations (13 million ha; Iremonger et al., 1997) has a smaller impact (provided that the timber is suitable for nesting) than conversion to agricultural land (Jaffe et al., unpubl. data).

A computer model for the Cape floral region of South Africa, the natural distribution area of the Cape honeybee, shows that up to $30 \%$ of the natural habitat could be lost within the next 20 years, mainly through urbanisation, agricultural land use (Rouget et al., 2003) and climate change (Thomas et al., 2004). Indeed, the effects of climate change on a continental scale need to be investigated in order to assess its impact on honeybee populations.

\subsection{Honey hunting}

Honey hunting is traditionally practiced in many African countries (Crane, 1990) and results in the death of the colony harvested in most instances (Hussein, 2000). Hunting is discouraged in many countries through rural developmental programs aimed at favouring beekeeping as a sustainable economic empowerment scheme. These programs also help reduce habitat destruction, at least that generated by tree damage during honey hunting. Apart from the impact on the tree containing the nest, the use of fire to repel honeybees can trigger forest fires (Smith, 1962; Clauss, 1991).

\section{CONSERVATION MEASURES ALREADY IN PLACE}

\subsection{South Africa}

In South Africa, to remedy the Capensis Problem, a dividing line has been drawn to separate the area in which A. m. scutellata and A. $m$. capensis can be used for beekeeping activities (government notices R 159 (1993) and R 1674 (1999) under the Agricultural Pest Act 1983). This notice stipulates that no bees can be transported across the demarcation line separating the country into a southern A. m. capensis and northern A. m. scutellata part. In addition, all honeybee colonies north of this line that are infested with the parasite must be destroyed within $72 \mathrm{~h}$ of their discovery.

Restrictions on the import of hive products or beekeeping equipment into South Africa are regulated by the government notice R 1013 . The import of honeybees is prohibited by the Agricultural Pest Act 36 of 1983. These measures could prevent the introduction of foreign diseases to which South African bees are not adapted and to which they could be susceptible. Honeybees were introduced onto Robben Island during the 1980' and 1990's prior to the invasion of Varroa and tracheal mites. The island was thereafter declared a honeybee sanctuary through the amendment \# R458 of the Agricultural Pest Act, 1983 (Act \#36, 1983) that prohibits the import of honeybees or used beekeeping material onto the island.

The South African Biodiversity Act (10/2004; Government Gazette 8 Feb 2008) stipulates the preservation of local populations of honeybees and will place additional requirements on beekeeping practise after implementation.

\subsection{Other countries}

Kenya is enforcing very strict regulations for the import of live honeybees. Imports are subject to permission from the Ministry of Environment and the Zoological Department of Museums of Kenya and honey imported has to comply with standards established by the Kenyan Bureau of Standards. Madagascar also regulates the imports of honeybees through a decree in 2004 from the Ministry of Agriculture, Breeding and Fisheries which is distinct from the Ministry regulating imports of other animals. Honeybee imports are subjected to permit from the Direction of Animal Production. Imports of honeybees that can become harmful to the local flora, honeybees or to humans are prohibited. Zambia classifies bees as being under the authority of their OIE (World organisation for Animal Health) contact point (Department of Veterinary and Livestock Diseases which falls within the Ministry of Cooperatives and Agriculture). The regulations of other countries are more general and do not 
apply only to honeybees, but to all imported animals. In Tunisia, honeybees and bee products imports have been regulated by a decree in 2002. The sanitary control of imported bees is done by the Veterinary Services of the Ministry of Agriculture and by the agents of the Public Health Ministry. Imported honey is also subjected to quality controls. In Nigeria, a decree in 1975 constituted the National Veterinary Research Institute whose role was to research animal diseases and establish control measures. Controls at the borders are the duty of the Nigerian Agricultural Quarantine Services, attached to the Ministry of Agriculture. The National Agency for Food and Drug Administration and Control certifies imported honey and bee products for distribution on the Nigerian market. The same situation occurs in Algeria, Cameroon, Gabon and Sao Tome, where decrees from the Ministries of Agriculture define general sanitary inspections of imported food, under which honey imports fall. However, no regulation exists regarding honeybee imports in these countries. Similarly, Congo Brazzaville, Mozambique and Burkina Faso do not regulate the import of honeybees. Some countries are in the process of establishing import regulations. The Ministry of Natural Resources and Tourism of Tanzania has been updating regulations in the last 8 years. At the time of formulation of the new regulations in 2001, the relevant laws were outdated and obsolete - such as the Produce Export (Beeswax) Rules of 1957 and the East African Customs Management Act of 1962 which regulated importation of honey, bees, beekeeping equipment and appliances. Since then, the Beekeeping Act (2002) and Beekeeping Regulations (2006) have been issued. They provide an updated legal framework for beekeeping in Tanzania, but further work needs to be done to improve and complete these regulations. Libya and Swaziland are also planning to update their regulations. Data for other African countries could not be collected.

Although some countries possess appropriate regulations, all suffer from a severe lack of technical capacity and often cannot proactively implement the regulations. However, despite the existence of regulations limiting honeybee and bee products movements and ir- respective of how well they are enforced, an important risk occurs through accidental shipments of swarms by air or land. Various examples of alien bee species entering a country (A. cerana and A. dorsata in Australia, A. florea in Sudan) have been reported. Only Australia and England (Anderson, 2008; Brown et al., 2008) have developed a monitoring system at ports and container platforms to favour detection of invaders or new diseases at early stages and thus improve the chance of eradication.

\subsection{Developmental projects}

Beekeeping developmental projects can contribute to conservation of honeybees and their environment (cf above) as long as they are based on the use of local honeybee populations. However, developmental schemes provide mixed results and a number failed because they were based on honeybee colonies imported from Europe or Australasia (Lohr, 1998; Nel et al., 2000). Additional reasons for failure were the lack of appropriate socioeconomical models, low support from local government, and the absence of a support strategy.

\section{CONSERVATOIN POLICY: SUGGESTIONS}

\subsection{Necessity for conserving honeybees in Africa}

Conservation is needed to ensure healthy natural populations to act as a reservoir / buffer against loss due to occasional disease outbreaks and in order to sustain a beekeeping industry or traditional beekeeping. The European and American examples have shown that wild bees can be driven to extinction since they cannot be treated (Kraus and Page, 1995; Jaffe et al., unpubl. data). Although feral colonies that became tolerant to diseases can establish populations (Rinderer et al, 2001; Corrêa-Marques et al., 2002; Le Conte et al., 2007), these feral populations remain localized and breeding them to reconstitute beekeepers' stocks is not straightforward and their use has not been widespread to date. 


\subsection{Nesting sites}

Although the effects of industrialization or agricultural landscapes are not ubiquitous in Africa, deforestation could represent a threat to honeybee populations and nesting sites should be protected.

\subsection{Developmental projects}

The use of non-indigenous honeybees in development projects has led to their failure and use of indigenous populations should be a requirement for the conservation of biodiversity. Determining conservation units within which colonies could be caught and used for such projects is difficult since population dynamics of $A$. mellifera are poorly defined and high migration rates occur (Schneider at al., 2004; Jaffe et al., 2009). The best approach would therefore be to use colonies trapped locally in development projects.

\subsection{Prevention}

Monitoring and trapping colonies around container ports or airports to monitor arrival of potentially invasive species or diseases should be undertaken so as to increase the probability of eradication before establishment. However, this is expensive and regular monitoring by skilled agents will be necessary for this to be effectively implemented, thus requiring resources that are not available in most African countries. To further decrease the possibility of introducing foreign diseases or disturbing the equilibrium established by local honeybees with their environment through the import of competitors, regulations should be put into place and their measures implemented to prevent long range movement of honeybees.

\section{CONCLUSIONS}

Most honeybee diseases are present in Africa, without large scale deleterious effects. Indeed, African bees are resistant or adapted to most common parasites (Moretta et al., 1991;
DeJong, 1997; Guerra et al., 2000) and no epidemics have been reported. The factors that contribute to this probably include beekeeping management (small vs. large scale), absence of breeding, high genetic diversity and presence of a large wild stock population, less migration, less harvest, less stress that allow honeybees to defend themselves against parasites and diseases.

Most likely a combination of all factors contributes to the healthy situation of the honeybees of Africa. However, as was discovered with the capensis problem (see above), it is the wild population that was used to compensate for the colony losses. This population served as a source from which to restock the depleted population of managed bees and buffered the dramatic loss of managed bee colonies affecting the apicultural sector. Nevertheless, relying on the natural population is only possible when such populations remain healthy. The natural populations in Africa have to deal with the same factors that threaten the honeybee populations of Europe and the USA (diseases, habitat loss, imported diseases or parasites). Therefore steps should be taken to maintain and improve the current situation, such as preventive interdiction of bee transport over large distances to avoid stress which could reduce the bees' natural defence mechanisms and facilitate disease spread or invasive processes. Beekeeping in Africa at the moment relies on local bees, but such reliance should be ensured in the long term by the establishment of conservation policies destined to maintain nesting sites and ensure the persistence of a healthy wild population. The reduction of nest sites would not only reduce the carrying capacity of the ecosystem, but would also affect the success of absconding by the bees (non reproductive swarming). There is evidence that leaving an infected nest site (absconding) is a crucial way for honeybees to fight diseases and parasite (e.g. American foulbrood, Fries and Raina, 2003). Paradoxically, absconding is seen as an unfavourable trait amongst beekeepers who lose colonies in this way and this trait is actively selected against. Where they occur, breeding and selection against "unfavourable" traits and the selection for "favourable" traits 
should be reassessed to encourage resistance against disease.

Africa is the origin of Apis mellifera (Whitfield et al., 2006) and the only area in the world where a natural population exists on a large scale. Conservation would not only be necessary for the maintenance of unique populations, but also for whole ecosystems as well owing to the role honeybees play as major pollinators of natural flora. These honeybee populations also provide an important pollination service for the production of agricultural crops. The wild honeybee population of Africa represents a highly valuable genetic resource that should be preserved as a source of genetic material for managed honeybee populations where their pollination services are crucial to the agricultural economy.

\section{ACKNOWLEDGEMENTS}

We are grateful to the staff of the Swiss embassies in Africa who assisted us in the collection of data concerning regulations of honeybee and bee products imports. Financial support was provided by the Claude Leon foundation (CWWP). Some of this material is based upon work supported by the National Research Foundation of South Africa.

Est-il nécessaire de prendre des mesures de conservation des abeilles en Afrique?

\section{Apis / protection / Afrique / maladie / parasite / apiculture}

\footnotetext{
Zusammenfassung - Gibt es eine Notwendigkeit zu Erhaltungsmaßnahmen bei afrikanischen Honigbienen? Die Beziehung zwischen Menschen und Honigbienen hat in Afrika verschiedene Formen: In vielen Ländern wird Honigjagd praktiziert; In einigen Ländern ist die traditionelle Bienenhaltung in Körben oder Klotzbeuten weitverbreitet während andere moderne Bienenhaltungstechnologie einsetzen. Der hauptsächliche kontextuelle Unterschied $\mathrm{zu}$ anderen Weltregionen, in denen die Honigbienen entweder heimisch sind oder eingeführt wurden, ist die bedeutende Population von freilebenden Bienen, auf denen Honigjagd und Ausbeutung basieren. Im Gegensatz zu Europa machen bewirtschaftete Völker nur einen kleinen Teil der Honigbienenpopulation aus (14-18 aus 310 Mio). Weiterhin basiert die Bienenhaltung in Afrika weitgehend auf dem Fang von wilden Schwärmen und es wird keine oder nur wenig Bienenzucht
}

betrieben. Diese Unterschiede sind wichtig, wenn die Honigbienenpopulationen von den in anderen Teilen der Welt zu beobachtenden Abnahmen geschützt werden sollen. Für Afrika sollten daher besondere politische Maßnahmen entwickelt werden. Auf diesem Kontinent sind die Netzwerke, auf die sich Bienenhalter und die Bienenindustrie stützen können nur sehr schwach entwickelt, und es wurden nur wenige Untersuchungen über die Honigbienen durchgeführt. Es ist daher sehr schwer, genaue Informationen und Zahlen über den Gesundheitszustand der Honigbienenpopulationen zu erhalten und daraus abzuleiten, ob Schutzmaßnahmen notwendig sind. Angesichts der Größe der Wildpopulation und dem Fehlen von Berichten über Epidemien könnte man schließen, dass die Wildpopulation in Afrika nicht gefährdet ist und daher von den Imkern ausgebeutet werden kann. Obwohl afrikanische Honigbienen den meisten Krankheiten ausgesetzt sind, die weltweit Honigbienen schädigen und sie diesen widerstehen können, sind der Verlust von Habitaten und Bejagung zwei Faktoren, denen europäische Bienen in geringerem Ausmaß ausgesetzt sind (da freilebende Honigbienen praktisch nicht mehr vorkommen und die bewirtschafteten Völker in vom Menschen hergestellten Beuten leben). Diese und andere noch nicht identifizierte Faktoren (z. B. neue Krankheiten) können Honigbienen negativ beeinflussen und ihre Wirkung könnte unter Umständen zu Verlusten in ähnlichem Ausmaß führen, wie sie andernorts beobachtet werden. Um zu verhindern, dass etwas Ähnliches in Afrika passieren kann, schlagen wir die Schaffung und Verbesserung sowie eine effektive Inkraftsetzung von Regulationen vor, die auf eine Erhaltung der afrikanischen Honigbienen abzielen. Da Afrika das Ursprungsland von Apis mellifera darstellt und das einzige Weltgebiet, in dem eine große Wildpopulation erhalten ist, sind Anstrengungen zur Erhaltung nicht nur zum Erhalt von einzigartigen Populationen vonnöten, sondern auch, um das Funktionieren des Ökosystems und der landwirtschaftlichen Produktion sicherzustellen, die beide von den Bestäubungsleistungen der Honigbienen abhängig sind.

Erhaltung / Honigbienen / Afrika / Krankheiten / Bienenhaltung

\section{REFERENCES}

Allsopp M.H. (1997) The honeybee parasitic mite Varroa jacobsoni, S. Afr. Bee J. 69, 73-82.

Allsopp M.H. (2004) Cape honeybee (Apis mellifera capensis Eschscholtz) and Varroa mite (Varroa destructor Anderson \& Trueman) threats to honeybees and beekeeping in Africa, Int. J. Trop. Insect Sci. 24, 87-94. 
Allsopp M. (2006) Analysis of Varroa destructor infestation of Southern African populations, MSc Thesis University of Pretoria, South Africa.

Anderson D. (2008) Health regulations of bees in Australia, OIE symposium diagnosis and control of bee diseases, Freiburg i. Breisgau, 26-28 August.

Anderson R.H. (1980) Cape honeybee sanctuaries, S. Afr. Bee J. 52, 5-9.

Beekeeping Act (2002) The United Republic of Tanzania, [online] http://www.tnrf.org/node/5256 (accessed 23 January 2009).

Beekeeping Act (2006) The United Republic of Tanzania, [online] http://www.tnrf.org/node/7651 (accessed 23 January 2009).

Bradbear N. (1988) World distribution of major honeybee diseases and pests, Bee World 69, 15-17.

Brown M., Ward L., Budge G., Boonham N. (2008) Risk based inspections for detection of the small hive beetle (Aethina tumida), OIE Symp. Diagnosis and control of bee diseases, Freiburg i. Breisgau, 26-28 August.

Crane E. (1990) Bees and beekeeping: science, practice and world resources, Heinemann Newnes, Oxford.

Crane E. (1999) The World History of Beekeeping and Honey Hunting, Routledge, NY.

Clauss B. (1991) Bees and beekeeping in the North Western Province of Zambia, Forest Department and Integrated Rural Development Programme (IRDP), Beekeeping Survey, Ndola, Zambia, $131 \mathrm{p}$.

Clauss B. (1992) Bees and Beekeeping in the north western Province of Zambia. Mission Press, Ndola, Zambia.

Corrêa-Marques M.H., De Jong D., Rosenkranz P., Gonçalves L.S. (2002) Varroa-tolerant Italian honey bees introduced from Brazil were not more efficient in defending themselves against the mite Varroa destructor than Carniolan bees in Germany, Genet. Mol. Res. 1, 153-158.

Crewe R.M., Allsopp M.H. (1993) The Cape bee as a Trojan horse rather than the hordes of Genghis Khan, Am. Bee J. 133, 121-123.

DeJong D. (1997) Mites: varroa and other parasites of brood. In: Honey bee pests, predators, and diseases, in: Morse R.A., Nowogrodzki R. (Eds.), Ithaca, NY, Cornell University Press, pp. 279-327.

Danka R.G., Villa J.D. (1994) Preliminary observations on the susceptibility of Africanized honey bees to American foulbrood, J. Apic. Res. 33, 243-245.

De La Rúa P., Jaffé R., Dall'Olio R., Munozi I., Serrano J. (2009) Biodiversity, conservation and current threats to European honeybees, Apidologie 40, 263-284.

Dietemann V., Lubbe A., Crewe R.M. (2006) Human factors facilitating the spread of a parasitic honeybee in South Africa, J. Econ. Entomol. 99, 7-13.
Eardley C.D., Gikungu M., Schwarz M.P. (2009) Bee Conservation in Sub-Saharan Africa and Madagascar: Diversity, Status and Threats, Apidologie 40, 355-366.

EC (2004) Achievements in agricultural policy under commissioner Franz Fischler (Period 1995-2004) [online] http://ec.europa.eu/agriculture/publi/ achievements/text_en.pdf (accessed 23 January 2009).

El Shafie H.A.F., Mogga J.B.B., Basedow T.H. (2002) Studies on the possible competition for pollen between the honey bee, Apis mellifera sudanensis, and the imported dwarf honey bee Apis florea (Hym., Apidae) in North-Khartoum (Sudan), J. Appl. Entomol. 126, 557-562.

El-Niweiri T., El-Sarrag M.S., Neumann P. (2008) Filling the Sudan gap: the Northernmost natural distribution limit of small hive beetles, J. Apic. Res. 47, 183-184.

Fries I., Raina S. (2003) American Foulbrood and African Honey Bees (Hymenoptera: Apidae), J. Econ. Entomol. 96, 1641-1646.

Guerra J.C.V., Goncalves L.S., de Jong D. (2000) Africanized honey bees (Apis mellifera L.) are more efficient at removing worker brood artificially infested with the parasitic mite Varroa jacobsoni Oudemans than are Italian bees or Italian/Africanized hybrids, Genet. Mol. Biol. 23, 89-92.

Härtel S., Neumann P., Kryger P., von der Heide C., Moltzer G.J., Crewe R., van Praagh J.P., Moritz R.F.A. (2006) Infestation levels of Apis mellifera scutellata swarms by socially parasitic Cape honeybee workers (Apis mellifera capensis), Apidologie 37, 462-470.

Hassan A.R., Neumann P. (2008) A survey for the small hive beetle in Egypt, J. Apic. Res. 47, 185186.

Hepburn H.R., Guillarmod J. (1991) The Cape honeybee and the fynbos biome, S. Afr. J. Sci. 87, 70-73.

Hepburn H.R., Radloff S.E. (1998) Honeybees of Africa, Springer, Berlin, Heidelberg, New York.

Hussein M.H. (2000) Beekeeping in Africa, Apiacta 1, $32-48$

Ibrahim A., Spivak M. (2007) The relationship between hygienic behavior and suppression of mite reproduction as honey bee (Apis mellifera) mechanisms of resistance to Varroa destructor, Apidologie 37, 31-40.

Iremonger S., Ravilious C., Quinton T. (1997) A statistical analysis of global forest conservation, in: Iremonger S., Ravilious C., Quinton T. (Eds.), A global overview of forest conservation. Including: GIS files of forests and protected areas, version 2 . CD-ROM. CIFOR and WCMC, Cambridge, UK.

Jaffé R., Dietemann V., Crewe R.M., Moritz R.F.M. (2009) Temporal variation in the genetic structure of a drone congregation area: an insight into the population dynamics of wild African honeybees (Apis mellifera scutellata), Mol. Ecol., doi: 10.1111/j.1365-294X.2009.04143.x. 
Johannsmeier M.F. (2001) Beekeeping in South Africa, 3rd ed., revised, Plant Protection Research Institute Handbook No. 14, Agricultural Research Council of South Africa, Pretoria, South Africa.

Kajobe R., Roubik D.W. (2006) Honey-making bee colony abundance and predation by apes and humans in an Ugandan forest reserve, Biotropica 38, 210-218.

Kelatwang S., Garzuglia M. (2006) Changes in forest area in Africa 1990-2005, Int. Forest. Rev. 8, $21-$ 30.

Kidd A.D., Schrimpf B. (2000) Bees and bee-keeping in Africa, in: Blench R.M., MacDonald K.C. (Eds.), The Origins and Development of African Livestock: Archaeology, genetics, linguistics and ethnography, London, UCL Press, pp. 503-526.

Kraus B., Page E.R. (1995) Effect of Varroa jacobsoni (Mesostigmata: Varroidae) on feral Apis mellifera (Hymenoptera: Apidae) in California, Environ. Entomol. 24, 1473-1480.

Le Conte Y., De Vaublanc G., Crauser D., Jeanne F., Rouselle J.C., Bécard J.M. (2007) Honey bee colonies that have survived Varroa destructor, Apidologie 38, 566-572.

Lohr W. (1998) Micro-enterprises in sustainable beekeeping development, Bees Development 48.

Lundie A.E. (1940) The small hive beetle Aethina tumida, Sci. Bull. 220, Dept. Agric. Forestry, Government Printer, Pretoria, South Africa.

Matheson A. (1996) World bee health update 1996, Bee World 77, 45-51.

Mogga J.B. (1994) Comparison between the daily flight activity of Apis mellifera yemenitica $\mathrm{R}$ and Apis florea $\mathrm{F}$ in Khartoum, Apidologie 25, 490.

Mogga J.B., Abdin A.M.Z.E., Nagi S.K.A., Ali A.M. (1989) Apis florea in Sudan: some biological observations, Proc 4th Int Conf Apiculture in Tropical Climates, Cairo, Egypt, pp. 422-424.

Mondragón L., Spivak M., Vandame R. (2005) A multifactorial study of the resistance of honeybees Apis mellifera to the mite Varroa destructor over one year in Mexico, Apidologie 36, 345-358.

Moretta G., Gonçalves L.S., De Jong D., Bichuette M.Z. (1991) The effects of climate and bee race on Varroa jacobsoni Oud infestations in Brazil, Apidologie 22, 197-203.

Moritz R.F.A., Härtel S., Neumann P. (2005) Global invasions of the Western honeybee (Apis mellifera) and the consequences for biodiversity, Ecoscience $12,289-301$

Moritz R.F.A., Kraus F.B., Kryger P., Crewe R.M. (2007) The size of wild honeybee populations (Apis mellifera) and its implications for the conservation of honeybees, J. Insect Conserv. 11, 391-397.

Morse R.A., Flottum K. (1997) Honeybee pests, diseases, and predator, 3rd ed. Medina, OH (USA) A.I. Root Co.
Mostafa A.M., Williams R.N. (2000) New record of the small hive beetle in Egypt and notes on its distribution and control, Bee World 83, 99-108.

Nel E., Illgner P.M., Wilkins K., Robertson M.P. (2000) Rural Self-Reliance in Bondolfi, Zimbabwe: the role of beekeeping, Geogr. J. $166,26-34$.

Neumann P., Hepburn H.R. (2002) Behavioural basis for social parasitism of Cape honeybees (Apis mellifera capensis Esch.), Apidologie 33, 165-192.

Neumann P., Elzen P.J. (2004) The biology of the small hive beetle (Aethina tumida, Coleoptera: Nitidulidae): Gaps in our knowledge of an invasive species, Apidologie 35, 229-247.

Ntenga G.M., Mugongo B.T. (1991) Honey hunters and beekeepers: A study of traditional beekeeping in Babati District, Tanzania, International Rural Development Centre Working Paper 161. Uppsala, Sweden: Sveriges Lantbruksuniversitet.

Ongus J.R. (2006) Varroa destructor virus 1: A new picorna-like virus in Varroa mites as well as honey bees, Thesis Wageningen Univ. [online] http:// library.wur.nl/wda/dissertations/dis3932.pdf (accessed 23 January 2009).

Rinderer T., De Guzman L.I., Delatte G.T., Stelzer J.A., Lancaster V.A., Kunetsov V., Beaman L., Watts R., Harris J.W. (2001) Resistance to the parasitic mite Varroa destructor in honey bees from far-eastern Russia, Apidologie 32, 381-394.

Ritter W., Michel P., Bartholdi M., Schwendemann A. (1990) Development of tolerance to Varroa jacobsoni in bee colonies in Tunisia, Proc. Int. Symp. on Recent research on bee pathology, September 5-7, Ghent, Belgium.

Rouget M., Richardson D.M., Cowling R.M., Lloyd J.W., Lombard A.T. (2003) Current patterns of habitat transformation and future threats to biodiversity in terrestrial ecosystems of the Cape Floristic Region, S. Afr. Biol. Conserv. 112, 6385.

Ruttner F. (1977) The problem of the Cape bee (Apis mellifera capensis Escholtz): parthenogenesis size of the population - evolution, Apidologie 8, 281-294.

Schneider S.S., Grandi-Hoffman G., Smith D.R. (2004) The African honeybee: factors contributing to a successful biological invasion, Annu. Rev. Entomol. 49, 351-376.

Scholmke W., Schmolke M. (2003) Varroa has arrived in Zimbabwe, Bees Dev. J. 68, 13.

Sheppard W.S., Rinderer T.E., Mazzoli J.A., Stelzer J.A., Shimunaki H. (1991) Gene Flow between African- and European-Derived Honey Bee Populations in Argentina, Nature 349, 782-784.

Smith F.G. (1962) Beekeeping as a Forest Industry, Br. Commonwealth Forestry Conference, $6 \mathrm{p}$.

The South African Biodiversity Act (10/2004) Government Gazette 8 Feb 2008 [online] 
http://www.environment.gov.za/HotIssues/2008/ ABSregs/Final\%20ABS\%20Regulation\%20 08\%20February\%202008.pdf (accessed 23 January 2009).

Thomas C.D., Cameron A., Green R.E., Bakkenes M., Beaumont L.J., Collingham Y.C., Erasmus B.F.N., de Siqueira M.F., an Grainger M.F., Hannah L., Hughes L., Huntley B., van Jaarsveld A.S., Midgley G.F., Miles L., Ortega-Huerta M.A., Peterson A.T., Phillips O.L., Williams S.E. (2004) Extinction risk from climate change, Nature 427, 145-148.

Total transformation Agribusiness (2004) Situation analysis of beekeeping industry in Botswana,
Lesotho, Malawi, Mozambique, South Africa, Swaziland, Zambia and Zimbabwe [online] http:// www.beekeeping.com/articles/us/beekeeping_ regional_situational-analysis.pdf (accessed 23 January 2009).

Tribe G.D. (1983) What is the Cape bee? S. Afr. Bee J. 55, 77-87.

Whitfield C.W., Behura S.K, Stewart I., Berlocher H., Clark A.G., Johnston J.S., Sheppard W.S., Smith D.R., Suarez A.V., Weaver D., Tsutsui, N.D. (2006) Thrice out of Africa: ancient and recent expansions of the honeybee, Apis mellifera, Science 314, 642-645. 